\title{
Why Dutch Women are Still More Religious than Dutch Men: Explaining the Persistent Religious Gender Gap in the Netherlands Using a Multifactorial Approach
}

\author{
Joris Kregting $^{1} \cdot$ Peer Scheepers $^{2} \cdot$ Paul Vermeer $^{1} \cdot$ Chris Hermans $^{1,3}$
}

Received: 27 June 2018 / Accepted: 19 January 2019 / Published online: 28 January 2019

(c) The Author(s) 2019

\begin{abstract}
In many secular Western countries, women continue to demonstrate higher levels of religiosity than men. But why does this religious gender gap persist? In this research note, we set out to explain the religious gender gap in the Netherlands for three dimensions of religiosity: belief in God, frequency of prayer and frequency of church attendance. Using high quality national representative survey data from LISS (Longitudinal Internet Studies for the Social sciences), an empirical model is built combining social and psychological determinants. We find that the experience of health restrictions, the personality trait conscientiousness and the gender orientation masculinity contribute to an explanation for the gender gap in the Netherlands regarding all three dimensions of religiosity. For belief in God and frequency of prayer, an additional psychological explanation comes from the gender orientation femininity.
\end{abstract}

Keywords Religious gender gap $\cdot$ The Netherlands $\cdot$ Secularisation $\cdot$ Social and psychological explanations

Joris Kregting

j.kregting@kaski.ru.nl

Peer Scheepers

p.scheepers@maw.ru.nl

Paul Vermeer

p.vermeer@ftr.ru.nl

Chris Hermans

c.hermans@ftr.ru.nl

1 Faculty of Philosophy, Theology and Religious Studies, Radboud University, PO Box 9103, 6500 HD Nijmegen, The Netherlands

2 Faculty of Social Sciences, Radboud University, PO Box 9104, 6500 HE Nijmegen, The Netherlands

3 Department of Practical and Missional Theology, University of the Free State, Bloemfontein, South Africa 


\section{Introduction}

The religious gender gap has attracted the attention of many scholars (e.g. Baker and Whitehead 2016; Collett and Lizardo 2009; De Vaus and McAllister 1987; Devine 2013; Francis and Penny 2014; Hackett 2016; Hoffmann 2018; Miller and Stark 2002; Norris and Inglehart 2008; Schnabel 2016, Schnabel 2017; Sullins 2006; Trzebiatowska and Bruce 2012; Voas et al. 2013). Their attention has focused on gender differences concerning different dimensions of religiosity, such as belief in God, church attendance and prayer. More importantly, these scholars have focused on explanations for the religious gender gap using a wide range of sociological and psychological insights. The combination of multiple dimensions of the religious gender gap and multiple explanations for this gap has resulted mainly in consensus about the enormous complexity to understand the gap. It has been classified as "the sum of small differences" (Trzebiatowska and Bruce 2012:170), a "puzzle [...] resistant to easy solutions" (Voas et al. 2013: 281) and "a complicated mix of multiple factors" (Hackett 2016: 58). To do justice to this complexity, an extensive set of hypotheses must be tested. This is where the scientific study of the religious gender gap has often encountered restrictions. Most studies have succeeded to test one typical explanation; e.g. Norris and Inglehart (2008), and Penny et al. (2015). Sullins (2006) presented an extended model with different types of explanations for the gender gap regarding self-related religiousness, frequency of prayer and church involvement, with data from the American General Social Survey for 1998. However, this study only succeeded to fully explain the gender gap regarding church involvement.

In this research note, we will present the over-time development of the religious gender gap in the Netherlands and test an extensive set of social and psychological explanations for this gap. The Netherlands is a very interesting test case due to widespread secularisation (Bernts and Berghuijs 2016). Our descriptive and explanatory tests of the religious gender gap in the Netherlands are presented with high quality data. These data allow us to follow the development of the religious gender gap in the Netherlands, through national surveys of the last 50 years. Moreover, they allow us to test an extensive set of explanations for the current religious gender gap with a wide range of both social and psychological determinants. With this explanatory model, we aim to elaborate further on the work of Sullins (2006: 873), who stated: "As competing explanations, social factors are more powerful in some respects and measures, and personality factors are more powerful in others; both, however, are far more powerful as complementary explanations contributing to a combined multifactorial model for gender differences in religiousness." To resume, with high quality data and the focus on a Western European country with a very high level of modernisation and secularisation, this research note aims to answer two research questions, one descriptive and one explanatory: To what extent is the religious gender gap in the Netherlands persistent? and To what extent do social and psychological differences between Dutch men and women explain this gap? 


\section{Theories and Hypotheses}

There are many different theoretical social and psychological explanations for the religious gender gap. These theoretical insights concern social structural location, socialisation, risk preference, personality traits and gender orientation (Francis and Penny 2014; Schnabel 2018; Sullins 2006). In this section, we will present these theoretical insights briefly and derive determinants from them.

\section{Gender Differences Regarding Social Structural Location}

Explanations for the religious gender gap in terms of social structural location are about different social positions of men and women. This is built on a theory of gender role differentiation (Luckmann 1967): women have lower status and power positions than men, which drives different levels of religiosity (De Vaus and McAllister 1987; Hastings and Lindsay 2013). Building on modernisation theory, many scholars argue that these social gender positions have lost importance in post-industrial Western societies such as the Netherlands, which in turn should diminish the religious gender gap. Trzebiatowska and Bruce (2012:179) conclude that "enough women are now free of the social roles that coincidentally brought them into the orbit of organized religion to destroy the web of expectations that disposed them to be more favourable, as a class, to religion." To the extent that this claim is true, the religious gender gap should have disappeared altogether into non-significance. Yet, evidence for the proposition of 'faded' gender positions is scarce, if it exists at all. Moreover, there are certain characteristics regarding gendered social structural location that have explained the religious gender gap, to some extent, in previous research (e.g., Norris and Inglehart 2008; Voas et al. 2013). We distinguish between four types of different gender positions which affect religiosity; they concern a gendered division of education, economics, social ties and health.

\section{A Gendered Division of Education}

Scientific rationalism has often been related to the process of secularisation (Berger 1967; Bruce 2011). Methodological naturalism and scientific proof-based critical thinking negatively affect religiosity (Ruiter and Van Tubergen 2009). This worldview is at the heart of Western education. With educational expansion in Western societies-including the Netherlands-scientific rationalism has become widespread and this has incited secularisation (Reitsma et al. 2012). Educational expansion in the Netherlands is a process to which both men and women are exposed. However, because Dutch women started the process later in history, the current general level of education of Dutch women is still lower than that of Dutch men (Statistics Netherlands 2015a). Moreover, the level of scientific rationalism is probably not the same for all areas of education (Van der Werfhorst 2001). To study in areas of economics, mathematics or technology means a stronger focus on proof-based methods than to study in areas of the arts, psychology, the humanities or communication, 
for example. Dutch women are very poorly represented in highly scientific rationalized education (Hartgers et al. 2017). Therefore, our hypotheses regarding the gendered division of education are: The religious gender gap is due to differences in the level of education (1a) and in the level of scientific rationalism in education between Dutch men and women (1b).

\section{A Gendered Division of Economics}

The economic explanation for the religious gender gap has much affinity with Norris' and Inglehart's theory of existential security (2004, 2008). According to them, the "need for religious reassurance becomes less pressing under conditions of greater existential security" (2008: 4). Economic resources promote this existential security and contribute to secularization. In Western countries - and the Netherlands is no exception (Statistics Netherlands 2015b) — there are enduring gender disparities between men and women in status and power concentrated around economic resources, e.g. income, and these disparities contribute to the religious gender gap (Schnabel 2016). An alternative to income as an economic resource for existential security is work. In 2016, the American research center Pew showed that in predominantly Christian countries, the religious gender gap between women in the labour force and men in general is much smaller than the gap between women outside the labour force and men in general (Hackett 2016). Religious institutions often (still) advocate the traditional gender division of men in the labour force and women at home. As Voas et al. (2013: 264) state: "The conservative ethos of religious organisations validates and reinforces the choice [of a woman] to be a home-maker." More specific than whether or not people are in the labour force is the number of hours they work, especially in countries such as the Netherlands, where many women work part-time and most men full-time (Dirven and Portegijs 2017). From this gendered division of economics we derive two hypotheses: The religious gender gap is due to differences in income (2a) and working hours (2b) between Dutch men and women.

\section{A Gendered Division of Social Ties}

Religion is often associated with the care of people who are vulnerable (Woodhead 2008); the central theme of many religious institutions is 'love and compassion'. This closely matches the way many women live. Trzebiatowska and Bruce postulate this core connection between women and religion as follows (2012: 105): "[...] women may be more religious than men because they have a greater part to play in areas where religion is especially prevalent: birth, child-rearing, sickness and death". Even in a strongly modernized country as the Netherlands, there is a gendered division of care, reflected in, e.g., the performance of informal care, like regularly helping someone who suffers from disease or some other affliction (SCP 2015). Our hypothesis (3) regarding the gendered division of social ties is as follows: The religious gender gap is due to differences in informal care between Dutch men and women. 


\section{A Gendered Division of Health}

Norris and Inglehart (2008: 17) link their concept of existential security not only to economic resources, but also to health and conclude that "those reporting that they experienced poor health prove to be more religious than those saying that they were in very good condition." We relate health to social structural location because we assume that poor health contributes to social dependency and a lower status and power position, and consequently to existential insecurity which drives religiosity. We explicate health in terms of three aspects: selfperceived health, mental health and health restrictions. Regarding these aspects, Dutch women experience more concerns than Dutch men (Knoops et al. 2017), which results in the following hypotheses: The religious gender gap is due to differences in self-perceived health (4a), mental health (4b) and health restrictions $(4 c)$ between Dutch men and women.

\section{Gender Differences Regarding Socialisation and Risk Preference}

The religious gender gap is frequently related to different levels of risk preference between men and women (e.g. Collett and Lizardo 2009; Hoffmann 2018; Miller and Hoffmann 1995), although empirical tests do not unambiguously confirm this link (Freese 2004; Freese and Montgomery 2007; Roth and Kroll 2007). Religiosity can be seen as a risk analysis strategy that helps the faithful to resist anxieties and promises salvation after death (Norris and Inglehart 2008). If women are less willing to take risks than men, this will positively affect their religiosity, compared to men. A sociological explanation for the gendered division of risk preference comes from power control theory (Collett and Lizardo 2009; Hagan et al. 1987) and focuses on socialisation. The theory states that in patriarchal families, where the father has higher social status than the mother, there is a power imbalance in family life that results in "reproducing the engendered schemas of patriarchal family life" (Hagan et al. 2002: 42). This means that a mother in a patriarchal family is assigned to the primary socialisation of her children and passes down the highly appreciated values of social and physical control to her daughters. In this way, daughters are indirectly taught to be restrictive in risk taking, while sons are not, or less so. The theory predicts that in patriarchal families, daughters' risk aversion affects their religiosity positively; compared to the tendency of risk preference for sons, which affects their religiosity negatively. In the Netherlands, the prevalence of patriarchal families, in terms of the father having a higher occupation and a higher education than the mother, is evident (Liefbroer and Dykstra 2000; Smits and De Vries 2013), which allows us to formulate two hypotheses regarding the gendered division of the socialisation of risk preference: The religious gender gap is due to the differences in socialisation of risk preference between Dutch sons and daughters in patriarchal families in which the mother had a lower occupational status than the father (5a) or in which the mother had attained a lower level of education than the father $(5 b)$. 


\section{Gender Differences Regarding Personality}

From a psychological perspective, Saraglou (2010) considers religion to be a cultural adaption of personality traits. He has demonstrated that agreeableness (the tendency to be concerned for others) and conscientiousness (the tendency to be attached to orderliness and self-control) positively affect religiosity. Saraglou concludes (2010: 119-120) that "religiousness thus clearly expresses [...] a human concern for personal and social stability and moral self-transcendence". The general link between neuroticism (the tendency to respond unstably to stressful situations) and religiosity has also been demonstrated, although not unambiguously (Francis and Jackson 2003; Saraglou 2002, 2010). Women have higher levels of agreeableness, conscientiousness and neuroticism, especially in countries with a high level of human development, such as the Netherlands (Schmitt et al. 2008). As a result, the hypotheses regarding the gendered division of personality are: The religious gender gap is due to differences in the levels of agreeableness (6a), conscientiousness (6b) and neuroticism (6c) between Dutch men and women.

\section{Gender Differences Regarding Gender Orientation}

Gender orientation relates to femininity and masculinity (Bem 1981). Femininity covers attributes, behaviours and roles that are strongly associated with compassion, affection and care. Therefore, people with a strong feminine orientation will be open minded to religion that has charity and sensitivity to people's needs as core values (Francis and Wilcox 1996, 1998; Thompson 1991; Thompson and Remmes 2002; Trzebiatowska and Bruce 2012). Masculinity, on the other hand, is associated with independency and leadership, which collide with religion that has a clerical executive power and that demands devotion (Thompson and Remmes 2002; Francis et al. 2001; Taylor 2007). In the Netherlands, Dutch women have a higher level of femininity and a lower level of masculinity than Dutch men (LISS 2012) which brings us to our hypotheses regarding the gendered division of gender orientation: The religious gender gap is due to differences in the levels of femininity (7a) and masculinity (7b) between Dutch men and women.

\section{Data}

For our descriptive analyses, in order to follow the persistence of the religious gender gap in the Netherlands, we use two national surveys that span religious developments in the Netherlands over the last decades. The first survey is 'God in the Netherlands', with five waves: 1966, 1979, 1996, 2006 and 2015. The second survey is 'Social and Cultural Developments in the Netherlands' (SOCON), with four waves: 1979, 2000, 2005 and 2011/2012. Data from these surveys are representative of the Dutch population. ${ }^{1}$

\footnotetext{
${ }^{1}$ For the data of God in the Netherlands, this is after the use of weighting factors which correct the somewhat skewed distributions in the surveys compared to the Dutch population, concerning age, gen-
} 
For our explanatory analyses, in order to test explanations for the religious gender gap in the Netherlands, we use data from the 'LISS (Longitudinal Internet Studies for the Social sciences) panel'; this panel consists of about 4500 Dutch households, comprising over 7000 individuals. $^{2}$ The explanatory analyses exclude respondents who are under 18 years of age or who have not completed their education and respondents over 70 years of age. The analyses include 1851 respondents with data for all dependent and independent variables, mostly for the year 2015.

\section{Dependent Variables}

Inspired by Stark and Glock (1968), we will differentiate between religious beliefs and practices. Religious belief is about transcendental devotion: belief in God. Religious practice is differentiated into private and public activities: frequency of prayer and of church attendance respectively. For a full description of the three dependent variables of our descriptive analyses, see "Appendix A". For a full description of the three dependent variables of our explanatory analyses and their descriptive statistics, see "Appendix B".

\section{Independent Variables}

Our explanatory model contains eighteen independent variables to test our hypotheses. "Appendix C" contains the descriptive statistics for the independent variables. The first independent variable is gender. Level of educational records the respondent's highest attained level of education and has six categories, recoded into three dummy variables: primary, secondary and higher level of education. Highly scientific rationalized education concerns education attained-or not-in the areas of economics, mathematics or technology. Income refers to the respondent's personal net monthly income out of work or other resources in Euros. Hours of work refers to the number of hours per week respondents are employed in their current job. Respondents who have no work, e.g. job seekers or disabled persons, were imputed zero hours of work per week. The independent variable hours of informal care refers to how many hours per week, on average over the year prior to the moment of survey, the respondent has helped someone who requires help due to a disease or other affliction. Self-perceived health of the respondent is a subjective description, with answer possibilities that range from 'poor' to 'excellent'. For mental health and health restrictions, scales have been constructed, respectively based on five (the Mental Health Inventory; Cronbach's alpha is 0.86) and three items (Cronbach's

\section{Footnote 1 (continued)}

der, education and region. The data from God in the Netherlands represent the Dutch population aged 17 years and older, and SOCON data the Dutch population between 18 and 70 years of age. All datasets, codebooks and questionnaires are available at https://dans.knaw.nl/en.

2 The panel is based on a true probability sample of households drawn from the population register by Statistics Netherlands. All datasets, codebooks and questionnaires are available at https://dans.knaw.nl/ en. 
Fig. 1 Belief in God or a higher power

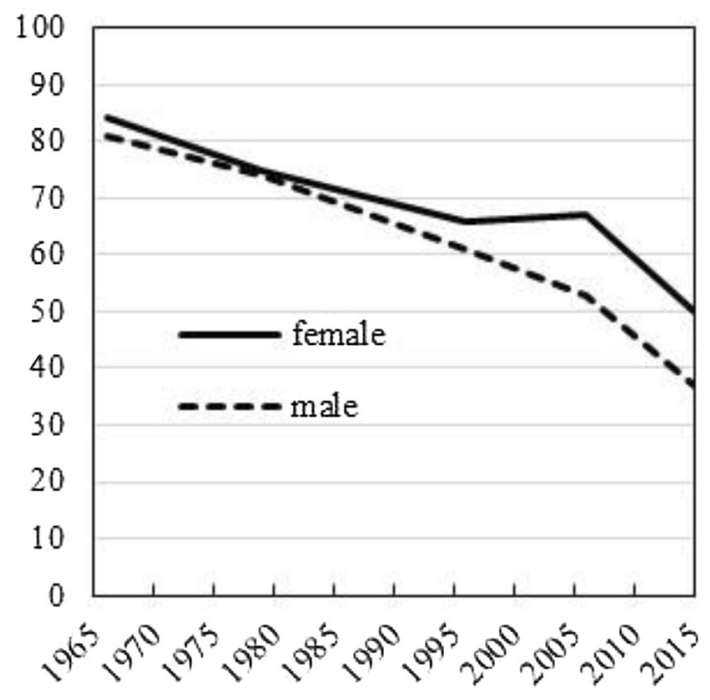

alpha is 0.90). Occupational and educational patriarchy in the family, respectively, are about difference in occupational status and level of education between the father and the mother during the respondent's formative years. ${ }^{3}$ Risk preference plays a central and intermediate role in the power control theory, measured by one single item, i.e. about how often one is prepared to take risks, ranging from 'rarely or never' to '(almost) always'. The scale for agreeableness is based on nine items (Cronbach's Alpha is 0.84), the scale for conscientiousness on seven items (Cronbach's Alpha is 0.77) and the scale for neuroticism on nine items (Cronbach's Alpha is 0.88 ); these personality scales are distracted from the International Personality Item Pool (Goldberg et al. 2006). The scale for femininity is based on ten items (Cronbach's Alpha is 0.89) and the scale for masculinity on nine items (Cronbach's Alpha is 0.83). ${ }^{4}$

As stated before, in our explanatory analyses, we have selected respondents who have completed their education, ranging from 24 up to 70 years of age. Because age could affect our other independent variables, e.g. regarding health or level of education, we will include age as a control variable.

\footnotetext{
3 When respondents have been raised in a single parent family, there is no difference between the social status of the father and the mother, and a difference of 0 has been imputed.

${ }^{4}$ Detailed information about the construction of the scales is available upon request from the first author.
} 
Fig. 2 Frequency of prayer, often or regularly

Fig. 3 Frequency of church attendance, regularly
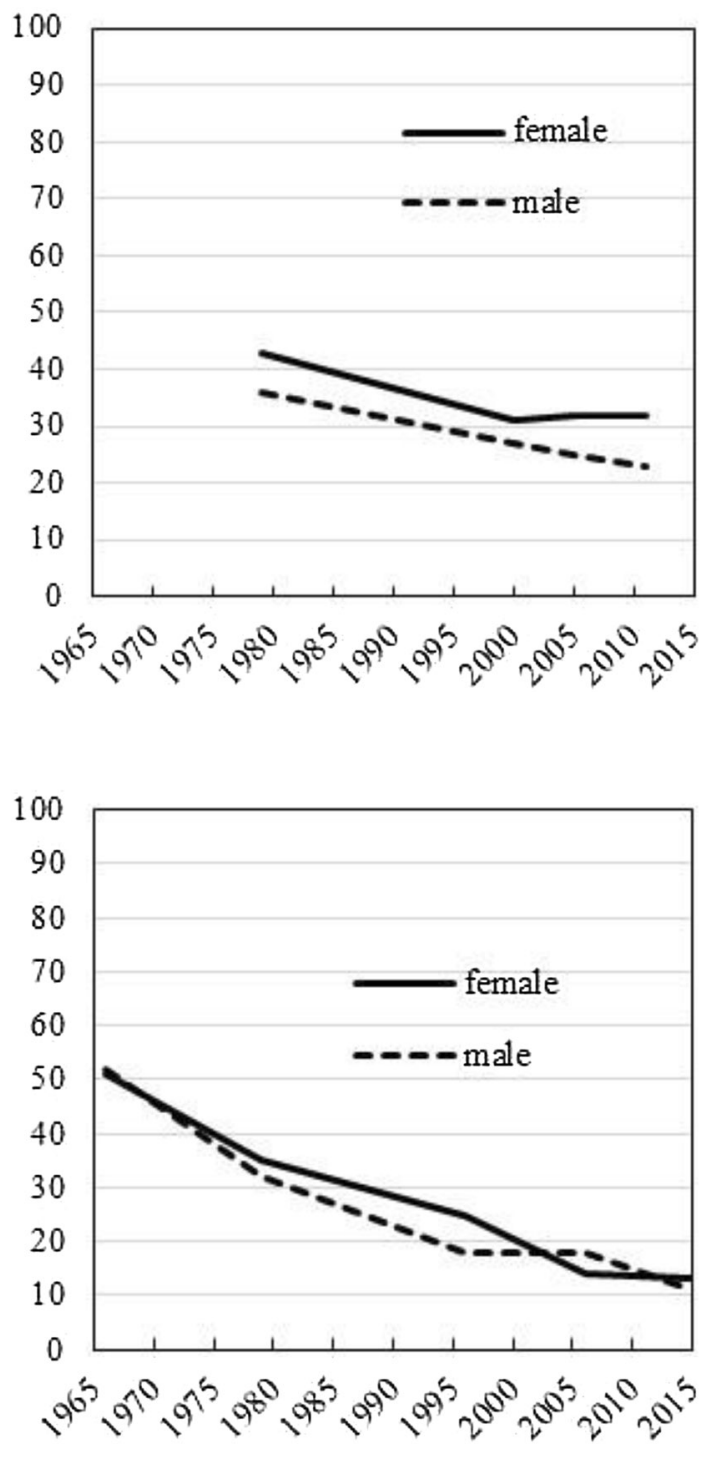

\section{Developments: Descriptive Analyses}

To answer our descriptive research question, let us follow the religious gender gap in the Netherlands over the last decades. In $1966,84 \%$ of Dutch women and $81 \%$ of Dutch men believed in God or a higher power (Fig. 1), a gap that was not significant; the same applies to the year 1979. But after that, the gender gap grew, and by 2015, $50 \%$ of Dutch women and $37 \%$ of Dutch men believed in God or a higher power. This 2015 gender gap is significant and, moreover, the biggest in the last five decades. For frequency of prayer, our earliest survey data are from 1979. In that year, 
$43 \%$ of Dutch women and 36\% of Dutch men prayed often or regularly-a significant gender gap (Fig. 2). This significant gap still existed in 2011/2012. At that time, $32 \%$ of Dutch women and $23 \%$ of Dutch men prayed often or regularly. Taking into account the negative trend, this recent gender gap regarding frequency of prayer is the biggest of the last decades. The increases in both gender gaps are also significant (ANOVA, $p<.05$ ). Our last dimension of religiosity, frequency of church attendance, shows only a very small gender gap for the entire period (Fig. 3). In 2015, $13 \%$ of Dutch women attended church regularly and $11 \%$ of Dutch men. This gap is not significant. Possibly, this has to do with the observation, that men and women mostly attend church together as married or cohabiting couples. We conclude that the religious gender gap in the Netherlands is persistent-and moreover, has significantly grown - concerning belief in God or a higher power and concerning frequency of prayer; however, for frequency of church attendance, there is no obvious gap.

\section{Multivariate Explanatory Analyses}

\section{Analytical Strategy}

We treat the three dependent variables—-belief in God, frequency of prayer and frequency of church attendance-as if they are continuous and use linear regression. ${ }^{5}$ Our explanatory analyses are built up through six models. Before focusing on explanations for the religious gender gap in the Netherlands, in model 1 we test the gender gap for our three dependent variables. In model 2, we test the relationships of gender with religiosity including determinants regarding social structural location and in model 3 including determinants regarding socialisation of risk preference (the interaction effects with gender look for different effects of this socialisation on boys and

\footnotetext{
5 Our analyses meet the standards of regression analysis regarding linearity between our independent and dependent variables, normality of residuals (Cook's distance values are far from the often used cutoff value of 1) and homoscedasticity (Field 2013). Mediation analysis is an appropriate strategy for our analyses. However, the program for mediation analysis, Process, does not allow more than ten independent variables as mediators-our final model has seventeen-and does not allow our dichotomous independent dummy variables regarding level of education and highly scientific rationalized education as mediators. As a test of robustness, we have performed mediation analyses with nine mediators between gender and our three dependent variables: level of education (continuous), income, hours of work, selfperceived health, health restrictions, conscientiousness, femininity, masculinity and age (see "Appendix D"). These mediators have been selected based on their significance in the models 5 and 6 in our analyses (with the exception of income, which purifies the mediation effect of hours of work). These mediation analyses demonstrate substantially similar results as our results of linear regression as presented in the final multifactorial models 6 of Tables 1,2 and 3. Exceptions are the results of hours of work regarding frequency of prayer and frequency of church attendance which are significant in mediation analyses but not in our models 6 . In addition, we have performed mediation analyses, with the nine mediators as stated before, with our three dependent variables recoded into dichotomous variables (see "Appendix D"). Again, results of these analyses are substantially very similar to our results of linear regression with the exception of the results of hours of work regarding frequency of prayer and frequency of church attendance.
} 


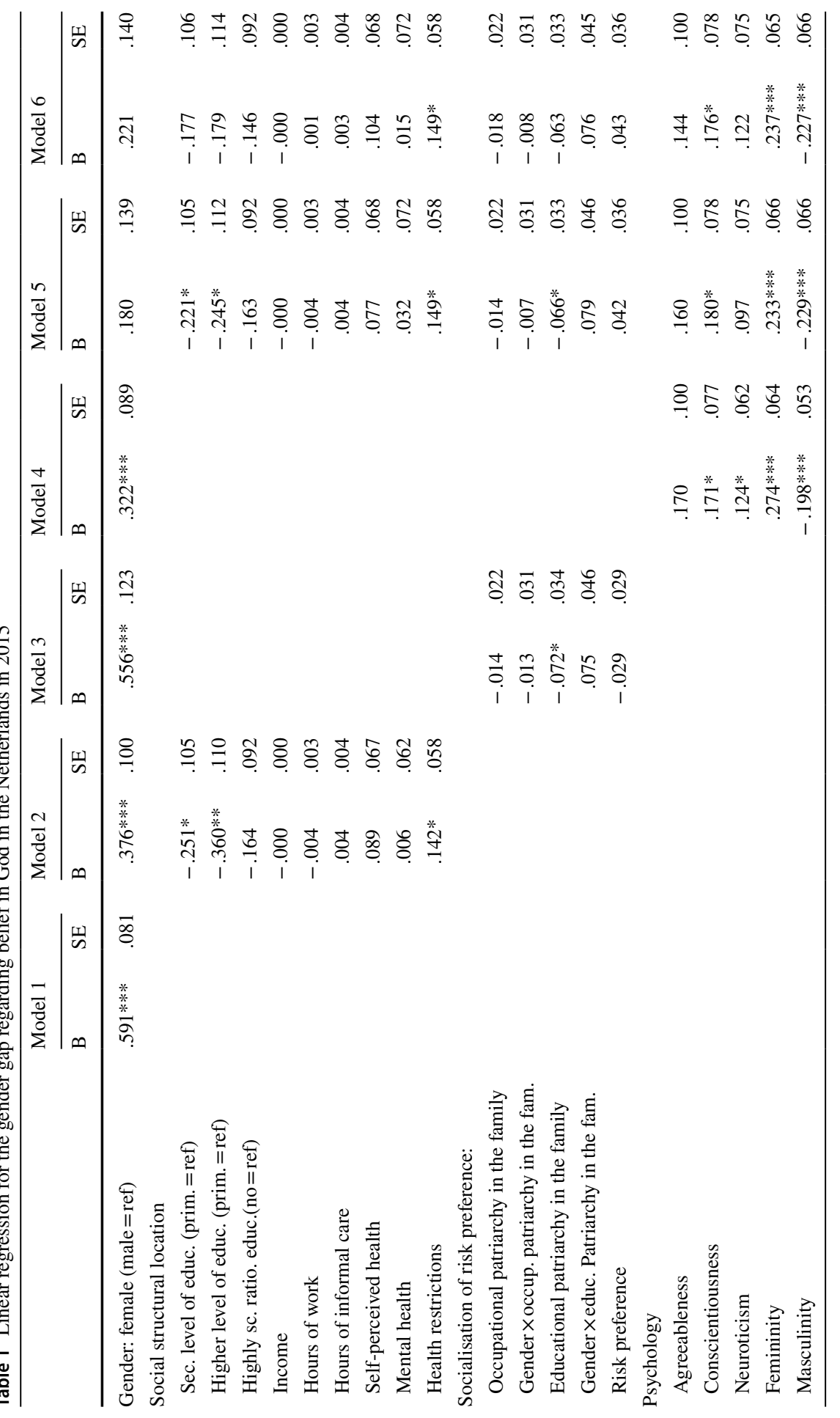




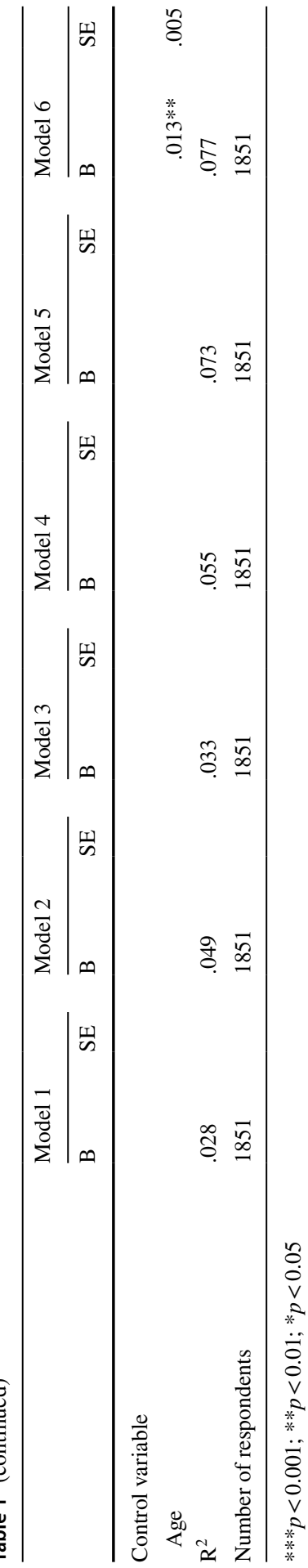

글 Springer 


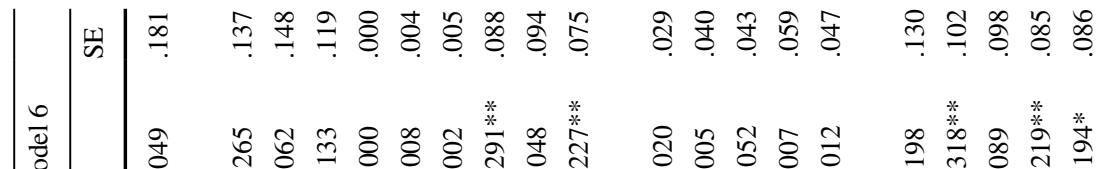

$$
\begin{aligned}
& \text { 乐 } \\
& \text { 出 } \\
& \text { 每 } \\
& \overrightarrow{9} \text { 후 } 8 \text { 용 }
\end{aligned}
$$

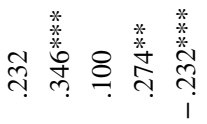

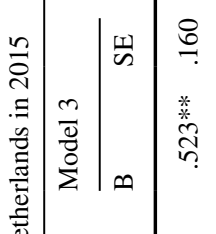

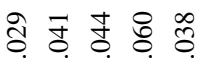

$$
\begin{aligned}
& \text { 운 }
\end{aligned}
$$

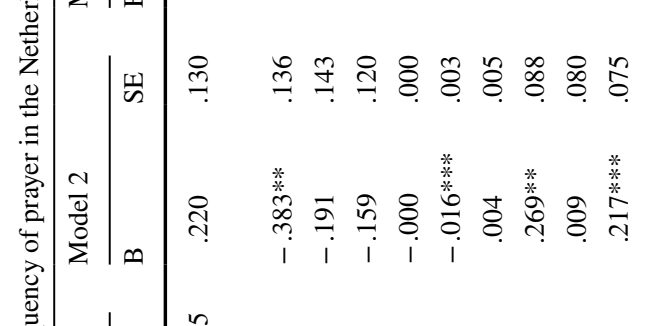

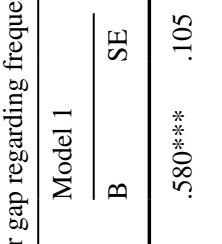

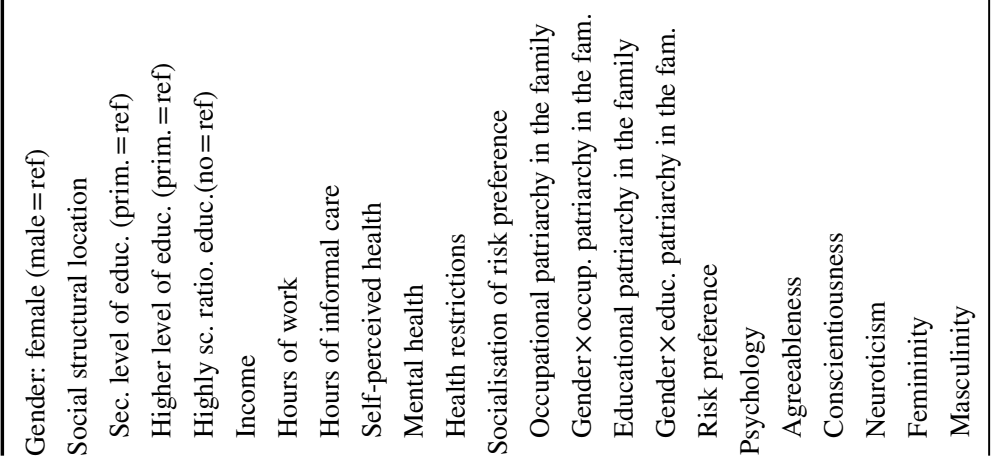




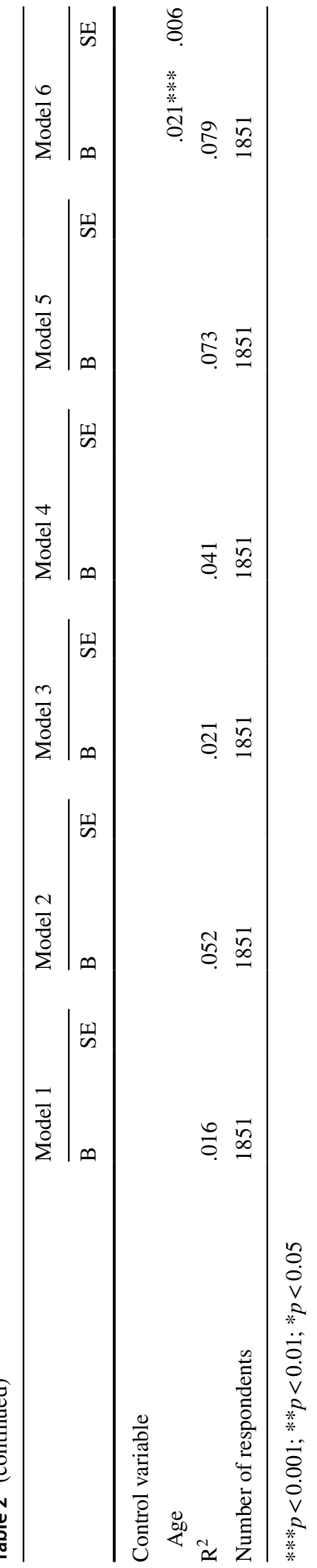

글 Springer 


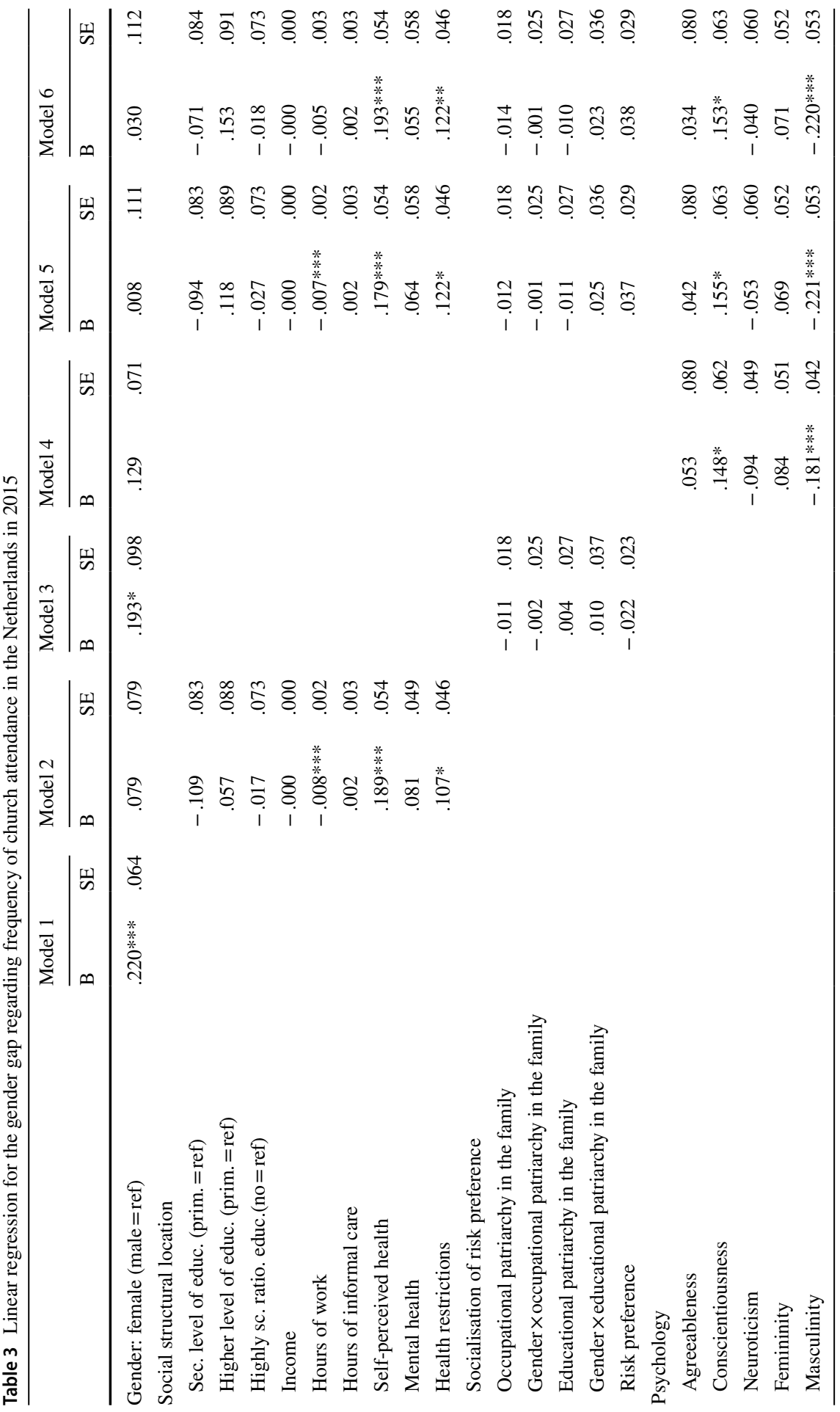




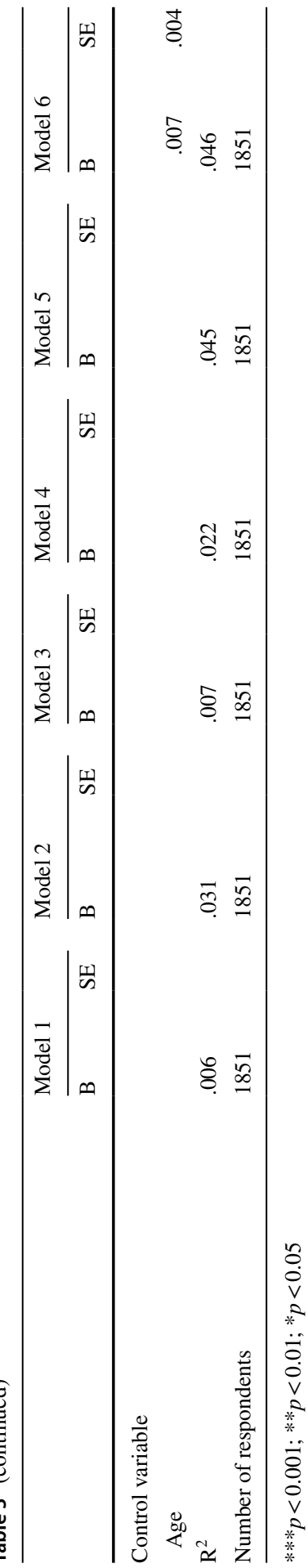

글 Springer 
girls; risk preferences serves as a control variable). In model 4, we integrate both psychological factors regarding personality and gender orientations. Model 5 tests the relationships of gender with religiosity after the inclusion of all the independent social and psychological determinants of models 1-4. This 'multifactorial' model provides insights into the complexity of a situation in which different determinants all contribute parts of the explanation for the religious gender gap, but together provide fuller insights (Sullins 2006). ${ }^{6}$ Finally, in model 6, we add the control variable age to our multifactorial model of analysis. In the description of our results, in order to test our hypotheses in the Conclusion and Discussion section, we will focus on this final multifactorial model 6.

All models have Variance Inflation Factors (VIFs) that do not exceed a value of 2.0, below the often used cut-off value (Meuleman et al. 2014). The models for the dependent variable belief in God are presented in Table 1, for frequency of prayer in Table 2 and for frequency of church attendance in Table 3. Effects are displayed as B coefficients.

\section{Results}

All three dimensions of religiosity demonstrate significant gender gaps in our models 1: Dutch women believe in God more strongly, pray more often and attend church more often than Dutch men. The gender gap regarding frequency of church attendance deviates from our descriptive analysis. This is a result of the use of different survey data for descriptive analyses (God in the Netherlands) and for explanatory analyses (LISS). ${ }^{7}$ In our final multifactorial models 6 in Tables 1, 2 and 3, the gender gaps regarding belief in God, frequency of prayer and church attendance are strongly reduced, actually reduced to non-significance.

Next, we focus on the determinants that explain these gender gaps. In Tables 1 and 2, our multifactorial models 6 demonstrate one social structural explanation and three psychological explanations for the gender gaps in the Netherlands regarding belief in God and frequency of prayer: these gaps are due to differences between Dutch men and women regarding health restrictions, conscientiousness femininity and masculinity. According to the multifactorial model 6 in Table 3, the same gendered determinants explain the gender gap regarding frequency of attendance in the Netherlands, with the exception of femininity. In the models for frequency of prayer

\footnotetext{
6 We have conducted separate analyses (UNIANOVA) on our three dependent variables, to test if there are significant interactions between gender and the other independent variables. A significant interaction effect in our analyses would mean that the relationship of an independent variable with a dependent variable is different for Dutch men and women. Because our hypotheses assume that the theoretical explanations apply to both Dutch men and women, a significant interaction effect would imply that the corresponding hypothesis would be falsified. However, our additional analyses show no significant interaction effects and therefore, they have been omitted.

7 According to God in the Netherlands, in 2015, 13\% of Dutch women attended church on 'a regular' base, compared to $11 \%$ of Dutch men; this gender gap is not significant. According to LISS, in 2015, $15 \%$ of Dutch women attended church 'at least once a month', compared to $11 \%$ of Dutch men; this gender gap is significant $(p<.01)$.
} 
and church attendance, the direction of the significant effect of self-perceived health is opposite to what we theoretically expected-a better self-perceived health contributes to a higher frequency of prayer and church attendance-and therefore this determinant does not explain the gender gap regarding these two religious practices.

\section{Conclusion and Discussion}

This study clearly answers our descriptive question about the persistence of the religious gender gap in the Netherlands. In the past decades, the gender gaps between Dutch men and women in terms of belief in God and frequency of prayer have not only persisted, they have widened significantly. The third dimension of religiosity, frequency of church attendance, shows a minimal gender gap, which is possibly due to the fact that men and women, at least if they are married or cohabiting, mostly attend church together as a couple. These descriptive results are in line with Sullins (2006), Norris and Inglehart (2008), and Voas et al. (2013). Our explanatory question is why - after a process of modernisation, with transformations of gender positions in many areas - these gaps persist in the Netherlands? In this final section, therefore, we match our results to our hypotheses (Table 4).

Our first theoretical insight regarding the religious gender gap in the Netherlands is about gendered social structural location: different gender positions in the areas of education, economics, social ties and health. The gendered level of education, the gendered level of scientific rationalism in education, gendered income, gendered hours of work and gendered informal care do not explain the religious gender gap in the Netherlands; our hypotheses $1 \mathrm{a}$ and $1 \mathrm{~b}, 2 \mathrm{a}$ and $2 \mathrm{~b}$, and 3 are not confirmed in the multifactorial analyses. The gendered division of economics has often been tested as an explanation for religious gender gaps. De Vaus and McAllister (1987), Sullins (2006), Dobbelaere et al. (2011) and Hackett (2016) attach importance to the gendered division of work as an explanation, Norris and Inglehart (2008) and Voas et al. (2013) to the gendered division of income. Our study does not support these earlier findings. Our last explanation for the religious gender gap in the Netherlands regarding social structural location is the gendered division of health. Our hypotheses about self-perceived and mental health (4a and 4b) are not confirmed, but our hypothesis concerning health restrictions (4c) is confirmed for all three dimensions of religiosity: because Dutch women experience more health restrictions than Dutch men, Dutch women believe in God more strongly, pray more often and attend church more often than Dutch men. Our finding that health restrictions contribute to an explanation for the Dutch religious gender gap is consistent with Norris and Inglehart's conclusion (2008) that women's vulnerability to poor health drives them to give higher priority to existential security and religion than men do.

With regard to the gendered division of socialisation of risk preference, our hypotheses (5a and 5b) are not confirmed. There are no significant interaction effects between gender and socialisation in a patriarchal family, which means that the difference between the social status of the father and of the mother-in terms of both occupational status and level of education-have no different effects on the religiosity of Dutch men and women. Our findings contradict those of Collett and Lizardo 
Table 4 Hypotheses and results of the religious gender gap in the Netherlands in 2015

Hypotheses: The religious gender gap in the Netherlands is due to differences...

Belief Frequency Frequency

in God of prayer of church

attendance

\footnotetext{
1a: In the level of education between Dutch men and women

$1 b$ : In the level of scientific rationalism in education between Dutch men and women
}

2a: In income between Dutch men and women

$2 \mathrm{~b}$ : In working hours between Dutch men and women

3: in informal care between Dutch men and women

4a: In self-perceived health between Dutch men and women

4b: In mental health between Dutch men and women

4c: In health restrictions between Dutch men and women

5a: In socialisation of risk preference between Dutch sons and daughters in patriarchal families in which the mother had a lower occupational status than the father

5 b: In socialisation of risk preference between Dutch sons and daughters in patriarchal families in which the mother had attained a lower level of education than the father

6a: In the level of agreeableness between Dutch men and women

6b: In the level of conscientiousness between Dutch men and women

6c: In the level of neuroticism between Dutch men and women

7a: In the level of femininity between Dutch men and women

$7 \mathrm{~b}$ : In the level of masculinity between Dutch men and women

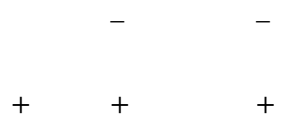

+: significant result in support of hypothesis,-: significant result in contradiction with hypothesis, empty cell: no significant result

(2009) in their study about power control theory. According to this theory, patriarchal socialisation has a different impact on risk preference among boys and girls and subsequently on religiosity. For the Netherlands, evidence for the second part of this argument is missing: risk preference does not contribute to religiosity. ${ }^{8}$

Regarding personality, the gendered division of conscientiousness offers a partial explanation for the religious gender gap in the Netherlands. This personality trait positively affects all three dimensions of religiosity; because Dutch women have a higher level of conscientiousness than Dutch men, Dutch women believe in God more strongly, pray more often and attend church more often than Dutch men. Our hypothesis about conscientiousness (6b) is confirmed. The other two personality traits, agreeableness and neuroticism, do not contribute to an explanation for the religious gender gap in the Netherlands; our hypotheses (6a and 6c) are not confirmed. The gendered division of personality has occasionally been tested as an explanation for the religious gender gap (Sullins 2006; Penny et al. 2015); however,

\footnotetext{
8 An additional analysis on our data shows evidence for the first part: patriarchal socialisation, in terms of both occupational status and level of education, positively affects the risk preference of Dutch men and negatively affects the risk preference of Dutch women.
} 
not in a multifactorial model with reliable scales for personality traits among representative samples. Our hypothesis (7a) regarding femininity is confirmed for belief in God and frequency of prayer. Femininity positively affects these two dimensions of religiosity; because Dutch women have a higher level of femininity than Dutch men, Dutch women believe in God more strongly and pray more often than Dutch men. Our last hypothesis (7b) is confirmed for all three dimensions of religiosity: the lower level of masculinity among Dutch women compared to Dutch men, contributes to a higher level of religiosity, in terms of belief in God, frequency of prayer and frequency of church attendance, among Dutch women compared to Dutch men. The significance of femininity and masculinity as an explanation for religious gender gaps has been put forward before, e.g., in studies from Francis and Wilcox (1996, 1998), Francis et al. (2001), Thompson (1991) and Thompson and Remmes (2002). However, these studies contained only small subgroups of populations, e.g., undergraduates, clergy or older men, rather than representative samples.

What all three religious gender gaps in the Netherlands have in common, is that they can partly be explained by gender differences in health restrictions, conscientiousness and masculinity. For belief in God and frequency of prayer, an additional explanation comes from gender differences in femininity. Remarkably, the religious gender gap in the Netherlands cannot be explained by social structural location, other than health restrictions, and the same applies to gender differences in socialisation of risk preferences. For all three dimensions of religiosity, we have managed to explain the religious gender gap. Prior to our study, Sullins (2006) achieved a similar result; however, this was limited to the gender gap regarding frequency of church attendance, the smallest of the religious gender gaps.

The religious gender gap is complex. In this research note, using high quality data that cover determinants regarding social structural location, socialisation, risk preference, personality and gender orientation, an extensive set of explanations for this gap found in the Netherlands has been tested. We have shown that even in this highly modernized and secularized Western country, a religious gender gap continues to exist. This gap, however, is not so much the result of gendered social structural location, but is rather due to gendered divisions of psychological determinants, in terms of personality and gender orientation, which seems to be persistent over time in the Netherlands.

OpenAccess This article is distributed under the terms of the Creative Commons Attribution 4.0 International License (http://creativecommons.org/licenses/by/4.0/), which permits unrestricted use, distribution, and reproduction in any medium, provided you give appropriate credit to the original author(s) and the source, provide a link to the Creative Commons license, and indicate if changes were made.

\section{Appendix A: Dependent Variables Descriptive Analysis}

Belief in God or a higher power (God in the Netherlands 1966-2015): Which of the following statements approximates your own conviction?

1. There is a God that looks after every person personally. 
2. There has to be something like a higher power that controls life.

3. I don't know whether a God or a higher power exists.

4. There is no God or higher power.

Frequency of prayer (SOCON 1979-2011/2012): Do you ever pray?

1. Often (recoded into 4)

2. Regularly (recoded into 3)

3. Sometimes (recoded into 2)

4. Never (recoded into 1)

Frequency of church attendance (God in the Netherlands 1966-2015): Do you regularly go to a church or religious community?

1. Regularly (recoded into 4)

2. Sometimes (recoded into 3)

3. Very occasionally (recoded into 2)

4. Never (recoded into 1)

\section{Appendix B: Dependent Variables Explanatory Analysis}

Belief in God: Which of the following statements best matches your idea of God?

1. I do not believe in God.

2. I do not know if God exists, and I do not believe that we have any way of knowing.

3. I do not believe in a God that is personally concerned with each of us, but I do believe in a higher power.

4. At some moments I do believe in God, at other moments I don't.

5. I believe in God, although I have my doubts.

6. I believe without any doubt that God exists.

Frequency of prayer: Aside from when you attend religious gatherings, how often do you pray?

Frequency of church attendance: Aside from special occasions such as weddings and funerals, how often do you attend religious gatherings nowadays?

1. Every day (recoded into 7)

2. More than once a week (recoded into 6)

3. Once a week (recoded into 5)

4. At least once a month

5. Only on special religious days (recoded into 3)

6. Less often (recoded into 2)

7. Never (recoded into 1)

See Table 5. 


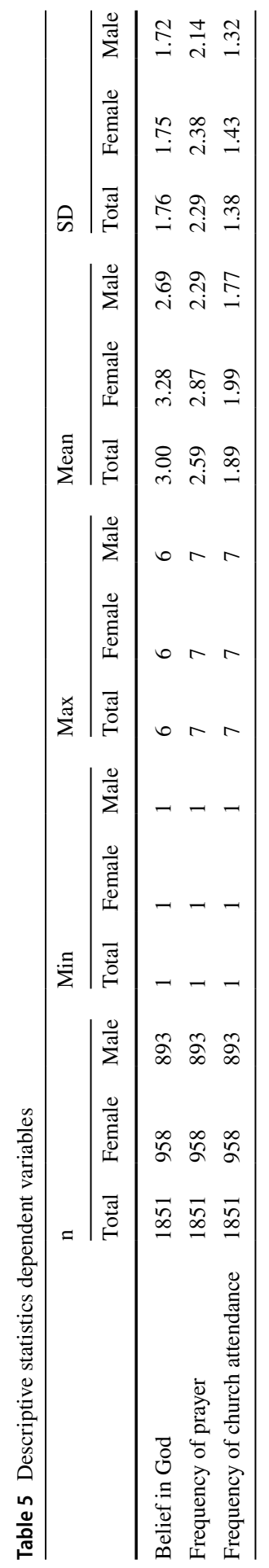




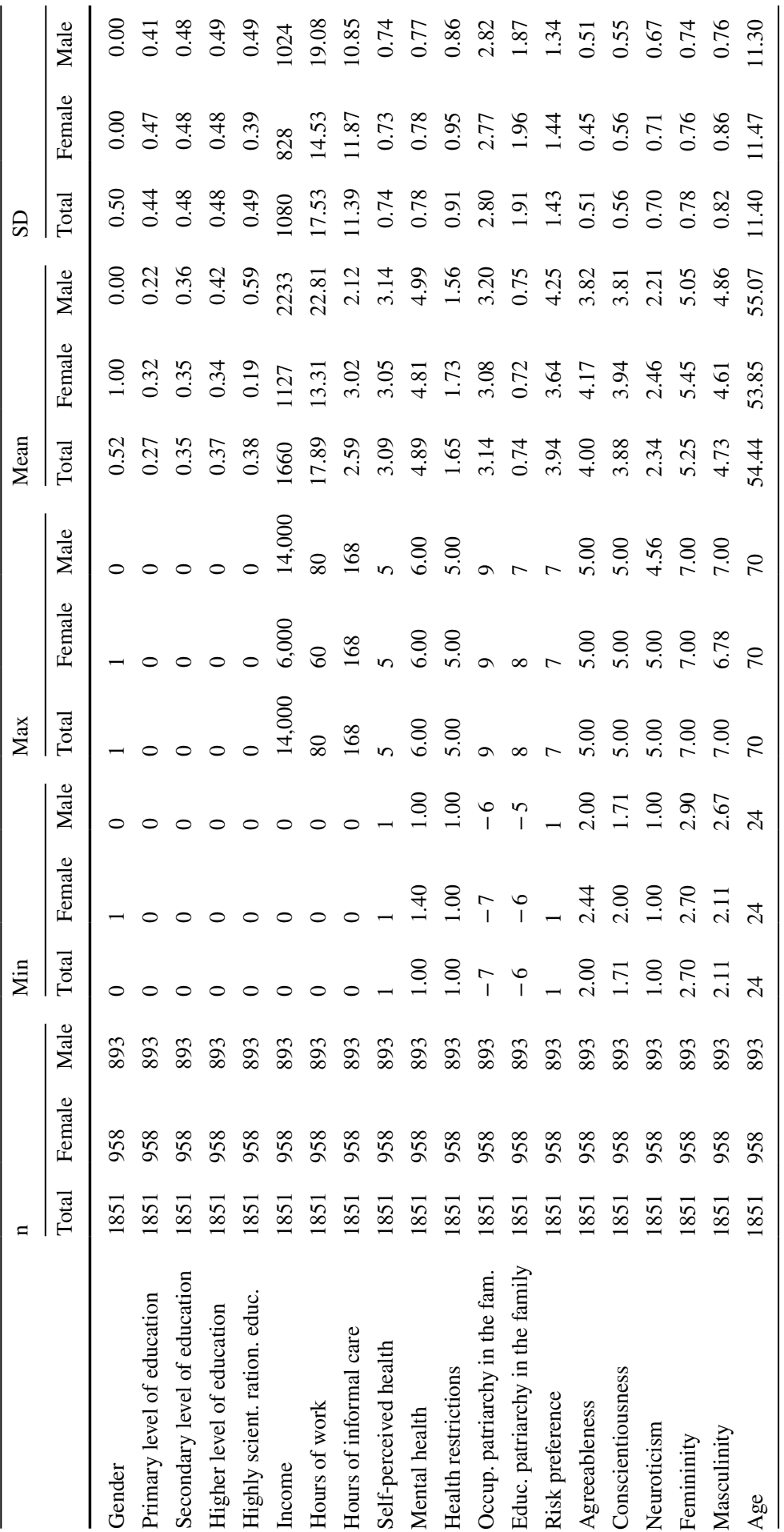




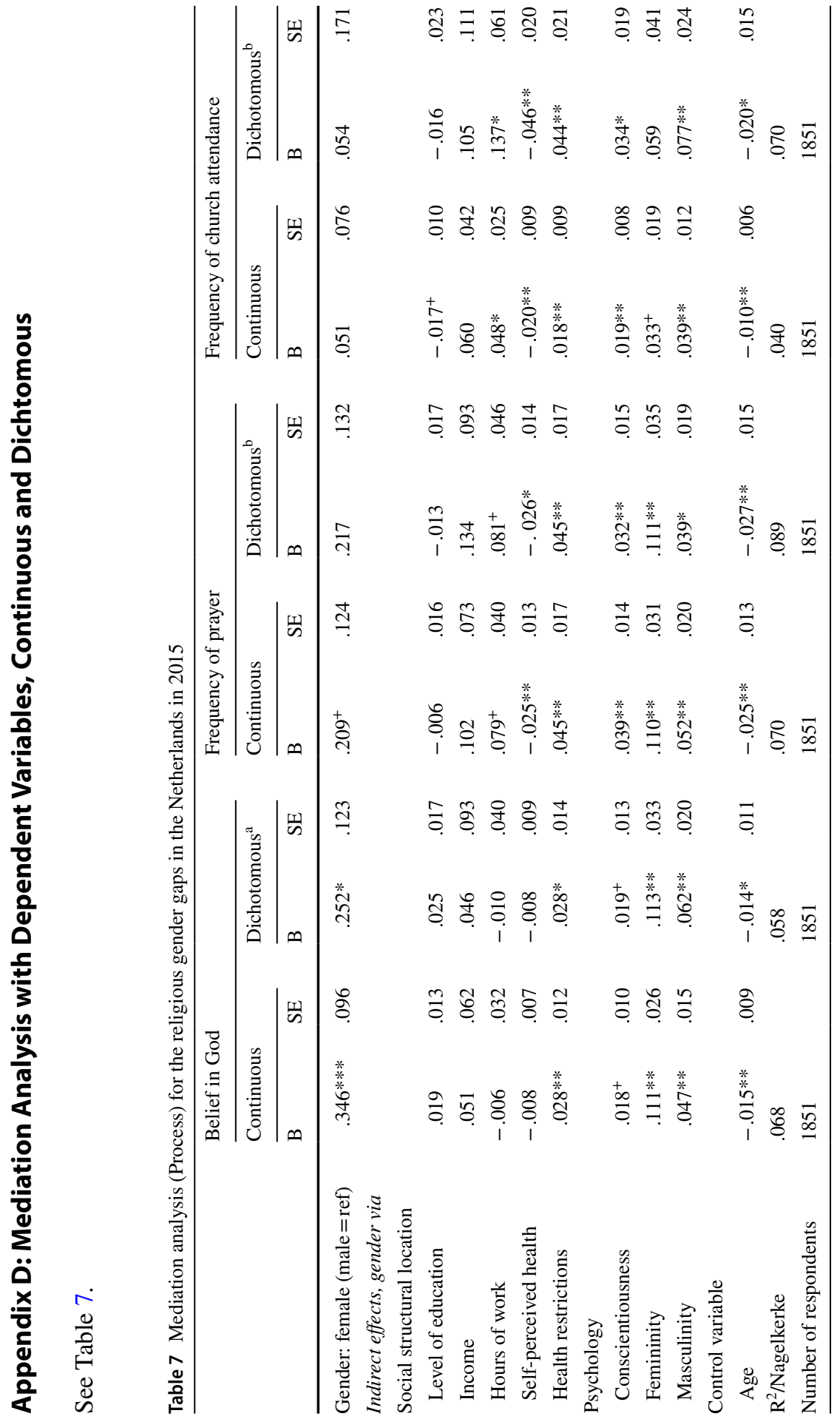




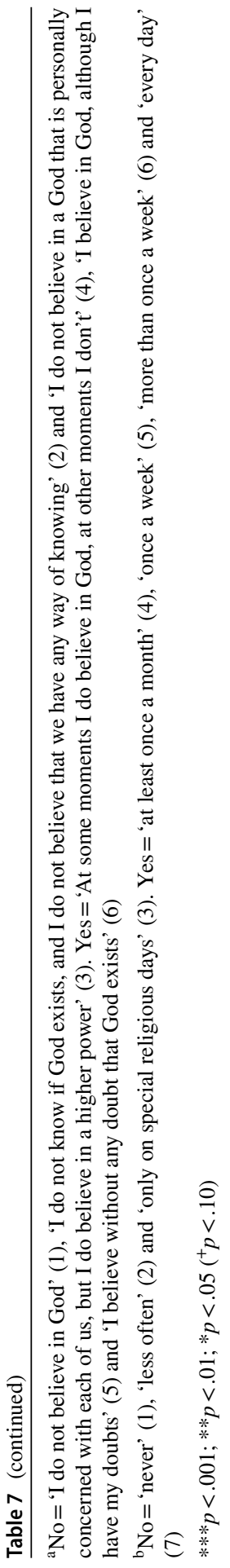




\section{References}

Baker, Joseph O., and Andrew L. Whitehead. 2016. Gendering (non)religion: Politics, education, and gender gaps in secularity in the United States. Social Forces 94(4): 1623-1645.

Bem, Sandra. 1981. Bem sex role inventory: Professional manual. Palo Alto, CA: Consulting Psychologists Press.

Berger, Peter Ludwig. 1967. The sacred canopy. New York: Doubleday.

Bernts, Ton, and Joantine Berghuijs. 2016. God in Nederland 1966-2015. Utrecht: Ten Have.

Bruce, Steve. 2011. Secularization. In defence of an unfashionable theory. Oxford: University Press.

Collett, Jessica L., and Omar Lizardo. 2009. A power control theory of gender and religiosity. Journal of Scientific Study of Religion 48(2): 213-231. https://doi.org/10.1111/j.1468-5906.2009.01441.x.

De Vaus, David, and Ian McAllister. 1987. Gender differences in religion: A test of the structural location theory. American Sociological Review 52(4): 472-481. https://doi.org/10.2307/2095292.

Devine, Paula. 2013. Men, women, and religiosity in Northern Ireland: Testing the theories. Journal of Contemporary Religion 28(3): 473-488. https://doi.org/10.1080/13537903.2013.831656.

Dirven, Henk-Jan, and Wil Portegijs. 2017. Arbeid. In Emancipatiemonitor 2016, ed. Wil Portegijs and Marion van den Brakel, 57-86. Den Haag: Sociaal en Cultureel Planbureau.

Dobbelaere, Karel, Jaak Billet, and Lilian Voyé. 2011. Religie en kerkbetrokkenheid: Naar een sociaal gemarginaliseerde kerk? In Nieuwe tijden nieuwe mensen. In Belgen over arbeid, gezin, ethiek, religie en politiek, ed. Koen Abts, Karel Dobbelaere and Lilian Voyé, 143-172. Leuven: Lanno Campus.

Field, A. 2013. Discovering statistics using IBM SPSS statistics. 4th ed. London: SAGE.

Francis, Leslie J., and Carolyn Wilcox. 1996. Religion and gender orientation. Personality and Individual Differences 20(I): 119-121.

Francis, Leslie J., and Carolyn Wilcox. 1998. Religiosity and femininity: Do women really hold a more positive attitude toward Christianity? Journal for the Scientific Study of Religion 37(3): 462-469.

Francis, Leslie J., and Chris J. Jackson. 2003. Eysenck's dimensional model of personality and religion: Are religious people more neurotic? Mental Health, Religion and Culture 6(1): 87-100. https://doi. org/10.1080/1367467031000086279.

Francis, Leslie J., S.H. Jones, C.J. Jackson, and M. Robbins. 2001. The feminine personality of male Anglican clergy in Britain and Ireland: A study employing the Eysenk Personality Profiler. Review of Religious Research 43: 14-23. https://doi.org/10.2307/3512240.

Francis, Leslie J., and Gemma Penny. 2014. Gender differences in religion. In Religion, personality and social behavior, ed. Vassilis Saraglou, 313-337. East Sussex: Psychology Press.

Freese, Jeremy. 2004. Risk preferences and gender differences in religiousness: Evidence from the World Values Survey. Review of Religious Research 46(1): 88-91. https://doi.org/10.2307/3512255.

Freese, Jeremy, and James Montgomery. 2007. The devil made her do it? Evaluating risk preference as an explanation of sex differences in religiousness. In Advances in group processes: The social psychology of gender, ed. Shelley Correll, 187-230. Oxford: Elsevier.

Goldberg, Lewis, John Johnson, Herbert Eber, Robert Hogan, Michael Ashton, Robert Cloninger, and Harrison Gough. 2006. The international personality item pool and the future of public-domain personality measures. Journal of Research in Personality 40: 84-96. https://doi.org/10.1016/j.jrp.2005.08.007.

Hackett, Conrad. 2016. The religious gender gap around the world. Washington, DC: Pew Research Center.

Hagan, John, Bill McCarthy, and Holly Foster. 2002. A gendered theory of delinquency and despair in the life course. Acta Sociologica 45(1): 37-46.

Hagan, John, John Simpson, and A.R. Gillis. 1987. Class in the household: A power-control theory of gender and delinquency. American Journal of Sociology 92(4): 788-816. https://doi.org/10.1086/228583.

Hartgers, Marijke, Ans Merens, Ronald Blokzijl, and Tanja Traag. 2017. Onderwijs. In Emancipatiemonitor 2016, ed. Wil Portegijs and Marion van den Brakel, 77-135. Den Haag: Sociaal en Cultureel Planbureau.

Hastings, Orestes P., and D.Michael Lindsay. 2013. Rethinking religious gender differences: The case of elite women. Sociology of Religion 74(4): 471-495. https://doi.org/10.1093/socrel/srt048.

Hoffmann, John P. 2018. Risk preference theory and gender differences in religiousness: A replication and extension. Journal of Scientific Study of Religion, version of record online 20 December 2018.

Knoops, Kim, Gerard Verweij, Ans Merens, and Ine Pulles. 2017. Gezondheid. In Emancipatiemonitor 2016, ed. Wil Portegijs and Marion van den Brakel, 214-244. Den Haag: Sociaal en Cultureel Planbureau. 
Liefbroer, Aart, and Pearl Dykstra. 2000. Levenslopen in verandering. Een studie naar ontwikkelingen in de levenslopen van Nederlanders geboren tussen 1900 en 1970, WRR voorstudies en achtergronden (V107). Den Haag: Sdu Uitgevers.

LISS. 2012. Study It's all about the party: Gender, party characteristics, and radical right voting. Available at: https://www.dataarchive.lissdata.nl/study_units/view/357.

Luckmann, Thomas. 1967. The invisible religion: The problem of religion in modern society. New York: Macmillan.

Meuleman, Bart, Geert Loosveldt, and Viktor Emonds. 2014. Regression analysis: Assumptions and diagnostics. In The SAGE handbook of regression analysis and causal inference, ed. Henning Best and Christof Wolf, 83-110. London: SAGE Publications Ltd. https://doi.org/10.4135/9781446288146.

Miller, Alan, and John Hoffmann. 1995. Risk and religion: An explanation of gender differences in religiosity. Journal for the Scientific Study of Religion 34(1): 63-75. https://doi.org/10.2307/1386523.

Miller, Alan, and Rodney Stark. 2002. Gender and religiousness: Can socialization explanations be saved? American Journal of Sociology 107(6): 1399-1423. https://doi.org/10.1086/342557.

Norris, Pippa, and Ronald Inglehart. 2004. Sacred and secular. Religion and politics worldwide. Cambridge: University Press.

Norris, Pippa and Ronald Inglehart. 2008. Existential security and the gender gap in religious values. (Draft chapter for the SSRC conference on religion and international affairs, New York, February 15-16, 2008 and the edited volume by Timothy Shah, Alfred Stepan, and Monica Toft).

Penny, Gemma, Leslie J. Francis, and Mandy Robbins. 2015. Why are women more religious than men? Testing the explanatory power of personality theory among undergraduate students in Wales. Mental Health, Religion and Culture 18(6): 492-502. https://doi.org/10.1080/13674676.2015.1079603.

Reitsma, Jan, Ben Pelzer, Peer Scheepers, and Hans Schilderman. 2012. Believing and belonging in Europe. European Societies 14(4): 611-632. https://doi.org/10.1080/14616696.2012.726367.

Roth, Louise Marie, and Jeffrey Kroll. 2007. Risky business: Assessing risk preference explanations for gender differences in religiosity. American Sociological Review 72(2): 205-220. https://doi. org/10.1177/000312240707200204.

Ruiter, Stijn, and Frank van Tubergen. 2009. Religious attendance in cross-national perspective: A multilevel analysis of 60 countries. American Journal of Sociology 115(3): 863-895. https://doi. org/10.1086/603536.

Saraglou, Vassilis. 2002. Religion and the five factors of personality: A meta-analytic review. Personality and Individual Differences 32: 15-25. https://doi.org/10.1016/S0191-8869(00)00233-6.

Saraglou, Vassilis. 2010. Religiousness as a cultural adaptation of basic traits: A five-factor model perspective. Personality and Social Psychology Review 14(1): 108-125. https://doi.org/10.1177/1088868309 352322.

Schnabel, Landon. 2016. The gender pray gap: Wage labor and the religiosity of high-earning women and men. Gender and Society 30(4): 643-669. https://doi.org/10.1177/0891243216644884.

Schnabel, Landon. 2017. Gendered religiosity. Review of Religious Research 59(4): 547-556. https://doi. org/10.1007/s13644-017-0302-9.

Schnabel, Landon. 2018. More religious, less dogmatic: Toward a general framework for gender differences in religion. Social Science Research 75: 58-72. https://doi.org/10.1016/j.ssresearch.2018.06.010.

Schmitt, David P., Anu Realo, Martin Voracek, and Jüri Allik. 2008. Why can't a man be more like a woman? Sex differences in Big Five personality traits across 55 cultures. Journal of Personality and Social Psychology 94(1): 168-182. https://doi.org/10.1037/0022-3514.94.1.168.

SCP. 2015. Informele hulp: Wie doet er wat? Omvang, aard en kenmerken van mantelzorg en vrijwilligerswerk in de zorg en ondersteuning in 2014. Den Haag: Sociaal en Cultureel Planbureau.

Smits, Wendy, and Robert de Vries. 2013. Sociaaleconomische trends 2013: Veranderende beroepsloopbanen van mannen en vrouwen. Den Haag: Centraal Bureau voor de Statistiek.

Stark, Rodney, and Charles Glock. 1968. American piety: The nature of religious commitment. California: University Press.

Statistics Netherlands. 2015a. CBS Statline, Bevolking; onderwijsniveau; geslacht, leeftijd en migratieachtergrond, 1 januari 2015. Available at: https://opendata.cbs.nl/statline/\#/CBS/nl/dataset/82275NED/table ?ts $=1529928968857$.

Statistics Netherlands. 2015b. CBS Statline, Beroeps- en niet-beroepsbevolking; gemiddeld inkomen en arbeidspositie, 1 januari 2015. Available at: https://opendata.cbs.nl/statline/\#/CBS/nl/dataset/83687 NED/table?ts $=1529932054287$.

Sullins, Paul. 2006. Gender and religion: Deconstructing universality, constructing complexity. American Journal of Sociology 112(3): 838-860. 
Taylor, Charles. 2007. A secular age. Cambridge: Harvard University Press.

Thompson, Edward. 1991. Beneath the status characteristic: Gender variations in religiousness. Journal for the Scientific Study of Religion 30(4): 381-394.

Thompson, Edward, and Kathryn Remmes. 2002. Does masculinity thwart being religious? An examination of older men's religiousness. Journal for the Scientific Study of Religion 41(3): 521-532. https://doi. org/10.1111/1468-5906.00135.

Trzebiatowska, Marta, and Steve Bruce. 2012. Why are women more religious than men? Oxford: Oxford University Press.

Van der Werfhorst, Herman. 2001. Field of study and social inequality Four types of educational resources in the process of stratification in the Netherlands. Nijmegen: ICS.

Voas, David, Siobhan McAndrew, and Ingrid Storm. 2013. Modernization and the gender gap of religiosity: Evidence from cross-national European surveys. Köln Z Soziol 65(1): 259-283. https://doi.org/10.1007/ s11577-013-0226-5.

Woodhead, Linda. 2008. Gendering secularization theory. Social Compass 55(2): 187-193. https://doi. org/10.1177/0037768607089738.

Publisher's Note Springer Nature remains neutral with regard to jurisdictional claims in published maps and institutional affiliations. 